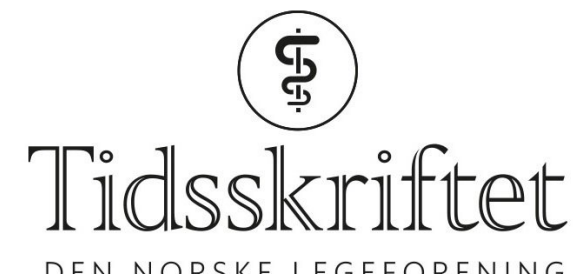

DEN NORSKE LEGEFORENING

\title{
Plan B
}

FRA REDAKTØREN

\section{RAGNHILD ØRSTAVIK}

E-post: ragnhild.orstavik@tidsskriftet.no

Ragnhild Ørstavik er assisterende sjefredaktør i Tidsskriftet. Hun er dr.med. og har en bistilling som seniorforsker ved Folkehelseinstituttet.

Nå foreligger revidert Plan S. Formålet om åpen publisering står fast, men det gis bedre tid til forberedelser og settes tydeligere krav til tidsskriftene. Det er mer enn betalingsmurer som skal rives.

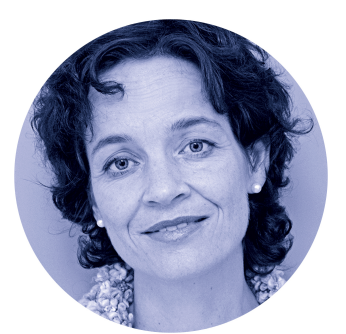

Foto: Einar Nilsen

Overgangen til åpen forskning gikk for sakte, mente en rekke europeiske forskningsråd, inkludert vårt eget, da de slo seg sammen og dannet Koalisjon S (1). I september 2018 lanserte gruppen Plan S. Fra 2020 skulle alle publikasjoner basert på forskning finansiert av dem være fritt tilgjengelig fra første dag. Slik ville de få slutt på at resultatene ble gjemt bak betalingsmurene til de tradisjonelle abonnementsbaserte tidsskriftene.

Sånt blir det bråk av: Ingen liker å bli fortalt hva de skal gjøre, i hvert fall ikke forskere (2). Kravene var for mange og for urealistiske, ytringsfriheten ble krenket og forvaltningsloven kanskje brutt (3).

I november ble prinsippene konkretisert i en veileder, som Koalisjon $S$ ba om skriftlige tilbakemeldinger på. I slutten av mai i år kom den reviderte planen (4). Koalisjonen har - til en viss grad - lyttet. Plan S er utsatt med ett år. I Norge vil for eksempel kravene gjelde fra og med utlysninger fra Forskningsrådet 1.1.2021. I tillegg er det tydeliggjort at finansiørene støtter flere former for åpen tilgang.

Det er tre alternative veier frem til Plan S-kompatibel publisering (4). Den første går gjennom tidsskrifter eller plattformer med åpen tilgang, med eller uten publiseringsavgift (henholdsvis gull eller platina åpen tilgang). Den andre er publisering $\mathrm{i}$ abonnementstidsskrifter som gir forskeren adgang til å deponere en innholdsmessig identisk versjon av artikkelen i et vitenarkiv. Plan $S$ godtar $i k k e$ å betale for å åpne enkeltartikler i abonnementsbaserte tidsskrifter. Den tredje publiseringsveien er åpen publisering gjennom såkalte transformative arrangements: Penger fra Plan S-finansiørene kan 
brukes til frikjøp dersom utgiver har inngått en overgangsavtale om åpen tilgang innen 2024. Uansett kanal må forsker eller institusjon beholde opphavsretten og publisere med en godkjent Creative Commons-lisens $(2,4)$.

Noen er bekymret for at overgangen til åpen tilgang vil føre til redusert kvalitet på det som publiseres (5). Koalisjon S er «fundamentalt uenig» i en slik oppfatning og hevder at detaljerte krav til tidsskriftene om å offentliggjøre økonomiske forhold, redaksjonell politikk og rutiner for fagvurdering vil sikre at forskerne kan velge tidsskrifter av høy kvalitet (6).

Åpen tilgang dreier seg først og fremst om hvordan kunnskap skal deles med alle

Formålet med Plan S er blant annet å presse de store forlagene vekk fra dyre abonnementsavtaler (5). Mye tyder på at dette allerede har hatt effekt: Siden i høst har norske institusjoner inngått publiser og les-avtaler med blant annet Wiley og Elsevier og er i forhandlinger med de andre store forlagene (7). Slike avtaler vil gjøre at enkeltforskerne ikke trenger å tenke på publiseringsavgift. Riktignok er Elsevier-tidsskriftet The Lancet unntatt fra avtalen, men de har gått med på å gi fra seg opphavsretten til forfatterversjonen av artikkelen, slik at denne kan deponeres (8). Dermed kan forskerne fremdeles publisere Plan S-kompatibelt i (enkelte) høyt rangerte tidsskrifter.

Høyt rangerte tidsskrifter er imidlertid et uttrykk som Koalisjon S kanskje helst ser at forsvinner. Motivasjonen bak Plan S er nemlig ikke bare å gjøre forskningen åpent tilgjengelig, men også å endre hvordan vi vurderer dens kvalitet. Når en forsker søker midler fra en finansiør som følger Plan S, skal komiteen vurdere innholdet i hver publikasjon, uten å skjele til hvilket tidsskrift arbeidet er publisert i. Komiteen skal følge prinsippene fra San Francisco Declaration on Research Assessment (DORA)-erklæringen, som Norges forskningsråd undertegnet allerede i fjor (9). Et slikt syn møter selvsagt motstand hos de aktuelle tidsskriftene selv, som ikke vil strippes for sin merkevare. Og som, en viss forfengelighet til tross, med rette insisterer på å være noe mer enn en publiseringskanal (8).

Selv om flere store forskningsfinansiører har erklært sin støtte til Koalisjon $S$ det siste året, er det fremdeles mange som ikke er med. Det kan derfor fremdeles være grunn til bekymring for redusert konkurransedyktighet og samarbeidsproblemer. Da må vi vende blikket vekk fra trærne og feste det på skogen, som Alison Muddit i PLOS minner om (10). Åpen tilgang dreier seg først og fremst om hvordan kunnskap skal deles med alle. Her er det mye som gjenstår.

\section{LITTERATUR:}

1. Science Europe. Plan S - Making full and immediate Open Access a reality.

https://www.coalition-s.org Lest 8.6.2019.

2. International Society for Medical Publication Professionals (ISMPP). A multistaker discussion on open access and medical publishing.

https://www.ismpp.org/assets/docs/Inititives/White_Papers/ISMPP_OA_White_Paper.pdf Lest 8.6.2019.

3. Khronos samlesider om Plan S. https://khrono.no/emne/open\%2oaccess Lest 8.6.2019.

4. Science Europe. Plan S. Principles and Implementation.

https://www.coalition-s.org/principles-and-implementation/ Lest 8.6.2019.

5. Brean A. Åpent. Tidsskr Nor Legeforen 2018; 138. doi:10.4045/tidsskr.18.o924. [PubMed][CrossRef]

6. Science Europe. Plan S. Rationale for the Revisions Made to the Plan S Principles and Implementation Guidance. https://www.coalition-s.org/rationale-for-the-revisions/ Lest 8.6.2019.

7. Åpen tilgang til forskning. Forhandlinger og hva de kan bety for framtidig tilgang. https://www.openaccess.no/forhandlinger-og-framtidig-tilgang.html Lest 8.6.2019.

8. The Lancet Group. Plan S: The final cut. Lancet 2019;393: 2276. [CrossRef] 
9. Forskningsrådet 22.5.2018. Forskningsrådet signerer DORA-erklæringen.

https://www.forskningsradet.no/nyheter/2018/forskningsradet-signerer-dora-erklaringen/ Lest

8.6.2019.

10. Muddit A. Plan S and the Transformation of Scholarly Communication: Are We Missing the Woods? The Scholarly Kitchen 3.6.2019.

https://scholarlykitchen.sspnet.org/2019/o6/o3/plan-s-and-the-transformation-of-scholarly-communic ation-are-we-missing-the-woods/ Lest 8.6.2019.

Publisert: 24. juni 2019. Tidsskr Nor Legeforen. DOI: 10.4045/tidsskr.19.0410

(C) Tidsskrift for Den norske legeforening 2020. Lastet ned fra tidsskriftet.no 